\title{
Influence of interleukin-6 gene polymorphism on the efficacy of antiviral treatment in patients with chronic hepatitis C
}

\author{
Yu. Yu. Riabokon*, K. V. Kalashnyk, O. V. Riabokon
}

Zaporizhzhia State Medical University, Ukraine

Key words: chronic hepatitis C, interleukin-6, genetic polymorphism, antiviral agents.

Zaporozhye medical journal 2019; 21 (1), 84-89 DOI: 10.14739/2310-1210 2019.1.155826

*E-mail: RyabokonZSMU@ gmail.com
Aim. The aim of the work was to determine the influence of interleukin-6 gene polymorphism on the effectiveness of antiviral therapy in patients with chronic hepatitis $\mathrm{C}$.

Materials and methods. A total of 83 patients with chronic hepatitis $\mathrm{C}(\mathrm{CHC})$. were included in the study. The efficacy of therapy with the peg-IFNa + SOF + RBV was analyzed depending on the polymorphism of interleukin-6 gene (rs1800795).

Results. All CHC patients with the CC genotype (14-100\%) responded to antiviral therapy with the peg-IFNa + RBV + SOF, but only $85.5 \%$ of the patients with CG/GG genotypes responded (59 of the 69 ). In CHC patients with CG/GG genotypes, who responded to the therapy by SVR 24 formation, the HCV-RNA negativization was slower, in contrast to patients with the CC genotype, who showed a persistent absence of the virus in the blood from the 4th week of treatment. All patients with the CC genotype of IL- 6 gene polymorphism presented complete normalization of ALT activity at this time if SVR 24 had been achieved. In the vast majority of CHC patients with SVR 24 and the CG/GG genotype after the therapy cessation, ALT activity continued to decrease and normalized after 24 weeks of observation in $94.9 \%$ (56 of the 59). However, $20.0 \%$ of patients with the CG/GG genotype who did not respond with the formation of SVR 24, had elevated serum ALT activity at the time of SVR 24 evaluation.

Kendall's rank correlation was performed to determine the factors, which statistically significantly affect the results of pegIFNa + RBV + SOF therapy. IL-6 gene polymorphism had an effect on the efficacy of therapy, both on the HCV-RNA negativization in the blood at the end of treatment $(P=0.04)$ and on the achievement of SVR $24(P=0.03)$. The lack of response as well as the lack of SVR 12 and SVR 24 formation at the time of therapy completion were associated with the IL-6 gene CG/GG polymorphism presence and a higher index of ALT activity at the beginning of treatment $(\tau=-0,18, P<0.01)$.

Conclusions. In CHC patients, the CC genotype of IL-6 gene (rs1800795) is a favorable prognostic factor for the formation of SVR 24 in the treatment of peg-IFNa + RBV + SOF. Patients who did not respond to the treatment by SVR 24 formation had only the IL-6 gene CG/GG polymorphism. Even in HCV patients with CG/GG genotypes who responded to the treatment by SVR 24 formation, the negativization of HCV-RNA in the blood was slower, unlike the patients with CC genotype. The absence of response at the time of therapy completion, as well as the absence of SVR 12 and SVR 24, were associated with the presence of the IL-6 gene CG/GG polymorphism and a higher level of ALT activity at the beginning of therapy $(\tau=-0,18, P<0.01)$.
Киючові слова: хронічний гепатит С, поліморфізм генетичний, інтерлейкін-6, противірусні засоби.

Запорізький медичний журнал. - 2019. T. 21, № 1(112). C. 84-89

\section{Вплив поліморфізму гена інтерлейкіна-6 на ефективність противірусного лікування хворих на хронічний гепатит С}

\section{Ю. Ю. Рябоконь, К. В. Калашник, О. В. Рябоконь}

Мета роботи - визначити вплив поліморфізму гена інтерлейкіна-6 на ефективність противірусної терапії хворих на хронічний гепатит С.

Матеріали та методи. У дослідження залучили 83 особи, які хворі на хронічний гепатит С (ХГС). Виконали аналіз ефективності противірусної терапії за схемою peg-IFNa + SOF + RBV залежно від поліморфізму гена інтерлейкіна-6 (rs1800795).

Результати. Встановили, що всі хворі на ХГС із генотипом СС (14 - 100 \%) відповіли на противірусну терапію за схемою peg-IFNa + RBV + SOF, але серед пацієнтів із генотипами CG/GG відповіли на лікування тільки 85,5% (59 із 69). У хворих на ХГC із генотипами CG/GG, які відповіли на ПВT формуванням CBB 24, негативація HCV-RNA у крові відбувалася повільніше, на відміну від пацієнтів із генотипами СС, в яких від 4 тижня лікування відзначено стійке зникнення вірусу. За умов досягнення СВВ 24 у всіх хворих із генотипом СС поліморфізму гена ІЛ-6 у цей термін спостереження відбулася нормалізація активності АлАТ. Здебільшого у хворих на ХГС із CBB 24 та CG/GG генотипом після припинення ПВТ активність АлАТ продовжувала знижуватися та нормалізувалася через 24 тижні спостереження у 94,9 \% (56 із 59). Але у 20,0\% пацієнтів, які не відповіли формуванням CBB 24 та мали генотипи CG/GG, на момент оцінювання CBB 24 активність АлАT у сироватці крові залишилася підвищеною.

Для визначення фракторів, які мають статистично значущий вплив на результати ПВТ за схемою peg-IFNa + SOF + RBV, здійснили рангову кореляцію за Кенделом. Поліморфізм гена ІЛ-6 мав вплив на ефективність ПВТ: як на негативацію HCV-RNA у крові на момент завершення лікування ( $p=0,04)$, так і досягнення CBB $24(p=0,03)$. Відсутність формування відповіді на момент завершення ПВТ, а також відсутність формування СВВ 12 і СВВ 24 асоціювалися з наявністю генотипів CG/GG поліморфрізму гена ІЛ-6 і вищим рівнем активності АлАТ до початку ПВТ $(\tau=-0,18$, $p<0,01)$.

Висновки. У хворих на ХГС генотип СС поліморфізму гена ІЛ-6 (rs1800795) є прогностично сприятливим щодо формування CBB 24 під час проведення ПBT за схемою peg-IFNa+SOF+RBV. Пацієнти, які не відповіли на лікування CBB 24, мали тільки генотипи CG/GG поліморфізму IЛ-6. Навіть і у хворих на ХГС із генотипами CG/GG, які відповіли на ПВТ формуванням СВВ 24, негативація HCV-RNA у крові відбувалася повільніше, на відміну від пацієнтів із генотипами CC. Відсутність формування відповіді на момент завершення ПВТ, а також відсутність СВВ 12 і СВВ 24 асоціювалися з наявністю генотипів CG/GG поліморфізму гена ІЛ-6 і вищим рівнем активності АлАТ до початку проведення ПВТ $(\tau=-0,18, p<0,01)$. 


\section{Влияние полиморфизма гена интерлейкина-6 на эффективность противовирусного лечения больных хроническим гепатитом С}

\section{Ю. Ю. Рябоконь, К. В. Калашник, Е. В. Рябоконь}

Цель работы - определить влияние полиморфизма гена интерлейкина-6 на эффективность противовирусной терапии больных хроническим гепатитом C.

Материалы и методы. В исследование включены 83 больных хроническим гепатитом С (ХГС). Проведен анализ эффективности терапии схемой peg-IFNa + SOF + RBV в зависимости от полиморфизма гена интерлейкина-6 (rs1800795).

Результаты. Установлено, что все пациенты с ХГС и генотипом CC (14 - 100\%) ответили на противовирусную терапию схемой peg-IFNa + RBV + SOF, при этом среди пациентов с генотипами CG/GG ответили на лечение лишь 85,5\% (59 из 69). У больных ХГC с генотипами CG/GG, которые ответили на ПВТ формированием CBO24, негативизация HCV-RNA происходила медленнее, в отличие от пациентов с генотипом СС, у которых уже с 4 недели лечения отмечено стойкое исчезновение вируса из крови. При условии достижения CBO24 у всех пациентов с генотипом CC полиморфизма гена IL-6 в эти сроки произошла полная нормализация активности АлАТ. У большинства больных XГC с CBO24 и CG/GG генотипами после прекращения ПВТ активность АлАТ продолжала снижаться и нормализовалась через 24 недели наблюдения у 94,9 \% (56 из 59). У 20,0 \% пациентов, которые не ответили формированием CBO24 и имели генотип CG/GG, на момент оценки СВО24 активность АлАТ в сыворотке крови оставалась повышенной.

Для определения факторов, которые имеют статистически значимое влияние на результаты ПВТ по схеме pegIFNa + RBV + SOF, проведена ранговая корреляция по Кенделлу. Полиморфизм гена IL-6 имел влияние на эффективность ПВТ: как на негативацию HCV-RNA в крови на момент завершения лечения $(p=0,04)$, так и на достижение CBO24 $(\mathrm{p}=0,03)$. Отсутствие формирования ответа на момент завершения ПВТ, а также отсутствие формирования СВО12 и CBO24 ассоциировались с наличием генотипов CG/GG полиморфизма гена IL-6 и более высоким показателем активности АлАТ в начале проведения ПВТ $(\tau=-0,18, p<0,01)$.

Выводы. У больных ХГC генотип CC гена IL-6 (rs1800795) является прогностически благоприятным фактором формирования CBO 24 при проведении ПВТ по схеме peg-IFNa + RBV + SOF. Пациенты, которые не ответили на лечение формированием CBO24, имели лишь генотипыCG/GG полиморфизма гена IL-6. Даже у больных XГC с генотипами CG/GG, которые ответили на ПВT формированием CBO24, негативация HCV-RNA в крови происходила медленнее, в отличие от пациентов с генотипом СС. Отсутствие формирования ответа на момент завершения ПВТ, а также отсутствие CBO 12 и СBO 24 ассоциировались с наличием генотипов CG/GG полиморфизма гена IL-6 и более высоким уровнем активности АлАТ до начала проведения ПВТ ( $\tau=-0,18, p<0,01)$.

Modern approaches to antiviral therapy (AVT) of chronic hepatitis $\mathrm{C}(\mathrm{CHC})$ have undergone substantial changes due to the development of antiviral drugs with a direct mechanism of action [1]. For a long time, a dual AVT was performed with pegylated interferon (peg-IFN) in combination with ribavirin (RBV) and had a low efficiency of $40-65 \%[2,3]$. The efficacy of peg-IFN + RBV treatment was clearly dependent on the hepatitis $\mathrm{C}$ virus (HCV) genotype, which required a different duration of AVT [4,5]. In addition to the viral factors, the age and gender of $\mathrm{CHC}$ patients, the disease duration, the degree of liver fibrosis severity, the presence of extrahepatic manifestations, and the results of previous etiotropic treatment were taken into account as the predictors of dual AVT efficacy [6,7].

In modern studies of $\mathrm{CHC}$ immunopathogenesis, researchers pay particular attention to defining not only the content of certain cytokines, but also the polymorphisms of genes encoding interleukins (IL). At the same time, the focus has been on the fact that the genetic polymorphism of certain cytokines affects not only the natural course of disease, but also the effectiveness of AVT. The clinical significance of the IL-28B gene polymorphism in the prediction of dual AVT efficacy by the peg-IFN + RBV scheme in patients infected with HCV genotype 1 is most clarified [8]. The IL-28B genotype of the CC gene has been shown to be associated with the highest frequency of a sustained virological response (SVR) to treatment achievement, but as the TT genotype, on the contrary, is associated with low efficacy of peg-IFN + RBV combination in CHC patients infected with HCV genotype 1 [9]. The clinical significance of IL-10 [10] and IL-15 [11] gene polymorphism was also demonstrated in the formation of virological response to peg-IFN + RBV treatment.

The development of 1 st generation direct-acting antiviral agents boceprevir (BOC) and telaprevir (TLV) allowed an increase in the efficacy of AVT in CHC patients infected with $\mathrm{HCV}$ genotype 1 by using the triple combination therapy of peg-IFN + BOC/TLV + RBV. According to the EASL (2012) [12] recommendations, which were in force at that time, a differentiated approach to choosing between dual or triple AVT scheme was advisable, taking into account the IL-28B gene polymorphism. These recommendations were based on the meta-analysis results [13], which demonstrated the absence of IL-28B polymorphism influence on the efficacy of triple AVT consisting of peg-IFN + BOC/TLV + RBV in $\mathrm{CHC}$ patients infected with HCV genotype 1.

The development of 2 nd generation direct-acting antiviral agents since 2014 has significantly reduced the duration of AVT and different treatment regimens have achieved effectiveness of $90 \%$ or more [1,14]. According to the current EASL recommendations (2016) [15], almost all treatment regimens, with the exception of the 3D regimen, include sofosbuvir (SOF), a potent inhibitor of HCV NS5B polymerase with a high genetic barrier to resistance and a favorable safety profile $[16,17]$. SOF is a nucleotide precursor of the active substance that converts intracellularly into the active uridine triphosphate analogue (GS-461203), which is capable of incorporating into HCV virion by NS5BRNA-polymerase resulting in termination of ribonucleic acid replication in the viral genome [18]. In Ukraine since 2015, AVT for $\mathrm{CHC}$ patients has been made possible according to the current treatment regimen of peg-IFN + SOF + RBV,
Киючевые спова: хронический гепатит С, полиморфизм генетический, интерлейкин-6, противовирусные средства. журнал. - 2019. T. 21, № 1(112). C. $84-89$ 
which lasts only 12 weeks regardless of HCV genotype [5]. Literature data indicate that the IL-28B polymorphism has no effect on the efficiency of SOF-based AVT $[8,19]$. The development of direct-acting antiviral drugs and the use of new combination treatment regimens require the search of new prognostic predictors for successful treatment.

\section{Aim}

The aim of the work was to determine the influence of interleukin- 6 gene polymorphism on the effectiveness of antiviral therapy in patients with chronic hepatitis $\mathrm{C}$.

\section{Materials and methods}

A total of 83 patients were examined and treated at the Hepatological Center of the Communal Institution "Zaporizhzhia Regional Clinical Infectious Disease Hospital" of the Zaporizhzhia Regional Council. Scheme of treatment were selected following the EASL 2016 recommendations and in accordance with the Protocol of the Ministry of Health of Ukraine N 729 dated 18.07.2016. The age of the patients ranged from 24 to 73 years, the median was $41.0(39 ; 51)$ years. There were 57 men and 26 women. The majority of patients had HCV genotype $1(52-62.7 \%)$ and genotypes $3(31-37.3 \%)$. The degree of liver fibrosis was determined using non-invasive methods (fibrosis test or elastometry), according to which F0 was detected in 4 (4/8\%), F1 in 8 (9.6\%), F2 in 38 (45.8\%), F3 in 27 (32.5\%), F4 in 6 (7.2\%) patients. The results of non-invasive ActiTest or the level of serum ALT elevation reflected the activity of inflammatory process in the liver. Activity A0 was found in $16(19.3 \%)$, $\mathrm{A} 1$ in 35 (42.1\%), A2 in 10 (12.0\%), A3 in 22 (26.5\%) patients. In the majority of patients $(53-63.9 \%)$, high viral load (more than 400 thousand $\mathrm{IU} / \mathrm{ml}$ ) was observed prior to AVT, and in $30(36.1 \%)$ patients it was low. All patients with a 12-week peg-IFN + SOF + RBV regimen were given an AVT course. The treatment effectiveness was evaluated by the formation of rapid virological response (RVR) after 4 weeks of AVT, virological response at the end of treatment, sustained virological response (SVR) at the 12th week and SVR 24 at the 24th week after the end of AVT.

Genotyping of IL-6 gene (rs1800795) polymorphism was performed on the basis of the Department of Molecular Genetic Studies of the Training and Laboratory Center of ZSMU (headed by Prof. O. M. Kamyshnyi) using the CFX96 Touch Real-Time polymerase chain reaction product detection system (BIO-RAD, USA) with sets of NP-512-100 (RU). The control group consisted of 45 healthy people. To study the effect of IL-6 gene (rs1800795) polymorphism on the AVT effectiveness, patients were grouped as follows: 14 patients with CC genotype; 69 patients with CG/GG genotype.

Statistical data processing was performed by using Statistica for Windows 13 (StatSoft Inc., № JPZ804I382130ARCN10-J). To assess the significance of differences between the quantitative features in the independent groups, the Mann-Whitney criterion was applied, and the quality method $x^{2}$ was used between qualitative features. The relationship between the studied parameters was evaluated by the method of Kendall's rank correlation.

\section{Results}

When comparing the basic laboratory data in patients with $\mathrm{CHC}$ depending on the IL-6 gene polymorphism at the beginning of AVT, it was found that the patients of studied groups did not differ statistically according to the virological testing results. So, the median of the viral load was $7.35 \times 10^{5}\left(3.40 \times 10^{4} ; 1.38 \times 10^{6}\right) \mathrm{IU} / \mathrm{ml}$ in patients with $\mathrm{CC}$ genotype versus $6.00 \times 10^{5}\left(2.23 \times 10^{5} ; 1.20 \times 10^{6}\right) \mathrm{IU} / \mathrm{ml}$ in patients with CG/GG genotype ( $P>0.05)$. In addition, the incidence of high (above $400000 \mathrm{IU} / \mathrm{ml}$ ) and low (below $400000 \mathrm{lU} / \mathrm{ml}$ ) viral loads also did not show a statistically significant difference between the study groups $(P>0.05)$. Comparison of necrotic-inflammatory changes and fibrosis intensity in the liver of patients with $\mathrm{CHC}$ depending on the IL-6 gene polymorphism showed that activity A2 of the inflammatory process severity was revealed in $\mathrm{CHC}$ patients with CC genotype of IL-6 gene polymorphism more often $\left(28.6 \%\right.$ vs. $\left.8.7 \%, X^{2}=4.34, P<0.05\right)$ than in patients with genotype CG/GG. However, the difference in the detection frequency of liver fibrosis different degrees in patients of the studied groups has not been revealed $(P>0.05)$.

The frequency of SVR 24 achievement was taken into account in the analysis of the AVT efficacy in $\mathrm{CHC}$ patients depending on IL-6 gene (rs1800795) polymorphism. Therefore, both the achievement of SVR 24 and IL- 6 gene polymorphism were included in the formation of $\mathrm{CHC}$ patient groups for the analysis of AVT efficacy. Taking all of this into account, it was found that all $\mathrm{CHC}$ patients with $\mathrm{CC}$ genotype $(14-100 \%)$ responded to the peg-IFNa + RBV + SOF scheme, but only $85.5 \%$ of CHC patients with CG/GG genotype responded to treatment ( 59 of the 69 ). It should be noted that only patients with CG/GG genotype (10 - 100\%) were among those who did not respond to treatment by SVR 24 achievement. In addition, in CHC patients with CG/GG genotype who responded to AVT by SVR 24, the negativization of HCV-RNA in the blood was slower in contrast to patients with CC genotype, who showed sustained viral suppression since the 4 th week of treatment. The course of AVT was accompanied by a decrease in the severity of cytolysis syndrome and normalization of serum ALT activity in most patients in all the studied groups. The normalization of ALT activity was observed with SVR 24 achievement in all patients with CC genotype of IL- 6 gene polymorphism in this observation period. In the vast majority of $\mathrm{CHC}$ patients with CG/GG genotype who achieved SVR 24, ALT activity continued to decrease after the end of AVT and normalized after 24-week follow-up in $94.9 \%$ (56 out of the 59). However, in patients with CG/GG genotype who did not respond to AVT by SVR 24 formation prior to the AVT, median activity of serum ALT was higher than in patients with SVR 24 during treatment, while the activity of serum ALT remained elevated at the time of SVR 24 evaluation in every fifth patient (Table 1).

The analysis of SVR 24 frequency under AVT with peg-IFNa + SOF + RBV regimen in $\mathrm{CHC}$ patients infected with different genotypes of HCV showed no statistically significant difference $(P>0.05)$ in the presence of IL-6 gene polymorphisms (rs1800795) (Table 2). Regardless of the cytokine gene polymorphism in all patient groups, there was a tendency towards a greater proportion of patients with genotype 1 of $\mathrm{HCV}$, which corresponds to the same pattern in the total number of $\mathrm{CHC}$ patients, namely infection with 
Table 1. Comparison of virological and biochemical response frequency to AVT with peg-IFNa + SOF + RBV regimen in CHC patients at different treatment periods depending on the achievement of SVR 24 and IL-6 gene polymorphism (rs1800795)

\begin{tabular}{|c|c|c|c|}
\hline \multirow{3}{*}{$\begin{array}{l}\text { Indicator, } \\
\text { units of measurement }\end{array}$} & \multicolumn{3}{|l|}{ CHC patients $(n=83)$} \\
\hline & \multicolumn{2}{|l|}{ Responders with SVR 24 ( $n=73$ ) } & \multirow{2}{*}{$\begin{array}{l}\text { Non-responders with SVR } 24(n=10) \\
\text { CG/GG genotype }(n=10)\end{array}$} \\
\hline & CC genotype $(n=14)$ & CG/GG genotype $(n=59)$ & \\
\hline \multicolumn{4}{|l|}{ Virological response to AVT } \\
\hline Viral load before treatment, $\mathrm{Me}\left(\mathrm{Q}_{25} ; \mathrm{Q}_{75}\right) \mathrm{MU} / \mathrm{ml}$ & $7,35 \times 10^{5}\left(3,40 \times 10^{4} ; 1,38 \times 10^{6}\right)$ & $6,01 \times 10^{5}\left(2,27 \times 10^{5} ; 1,40 \times 10^{6}\right)$ & $6,45 \times 10^{5}\left(4,38 \times 10^{5} ; 9,40 \times 10^{5}\right)$ \\
\hline RVR, abs. (\%) & $14(100.0 \%)$ & $56(94.1 \%)$ & $8(80.0 \%)$ \\
\hline Response at the end of AVT, abs. (\%) & $14(100.0 \%)$ & $59(100.0 \%)$ & $2(20.0 \%)$ \\
\hline SVR 12 , abs. (\%) & $14(100.0 \%)$ & $59(100.0 \%)$ & $0(0 \%)$ \\
\hline SVR 24 , abs. (\%) & $14(100.0 \%)$ & $59(100.0 \%)$ & $0(0 \%)$ \\
\hline \multicolumn{4}{|l|}{ Biochemical response to AVT } \\
\hline ALT before treatment, $\mathrm{Me}\left(\mathrm{Q}_{25} ; \mathrm{Q}_{75}\right) \mathrm{mmol} / \mathrm{h} . \mathrm{l}$ & $1.46(0.76 ; 2.26)$ & $1.19(0.66 ; 1.80)$ & $1.99(1.13 ; 2.26)^{*}$ \\
\hline Elevated ALT before treatment, abs. (\%) & $11(78.6 \%)$ & $42(71.2 \%)$ & $10(100.0 \%)$ \\
\hline Elevated ALT after 4 weeks of AVT, abs. (\%) & $7(50.0 \%)$ & $25(42.4 \%)$ & $4(40.0 \%)$ \\
\hline Elevated ALT at the end of AVT, abs. (\%) & $7(50.0 \%)$ & $19(32.2 \%)$ & $1(10.0 \%)$ \\
\hline Elevated ALT in 12 weeks after the end of AVT, abs. (\%) & $7(50.0 \%)$ & $19(32.2 \%)$ & $1(10.0 \%)$ \\
\hline Elevated ALT in 24 weeks after the end of AVT, abs. (\%) & $0(0 \%)$ & $3(5.1 \%)$ & $2(20.0 \%)$ \\
\hline
\end{tabular}

*: the difference is statistically significant as compared to $\mathrm{CHC}$ patients with CG/GG genotype who responded with SVR 24 formation $(P<0.05)$.

genotype $1 \mathrm{HCV}$ was recorded in $62.7 \%$ (52 of the 83), while infection with genotype $3 \mathrm{HCV}$ was in $37.3 \%$ (31 out of the 83) (Table 2).

In order to determine the factors that statistically significantly affect the AVT results with peg-IFN + RBV + SOF scheme, we used Kendall's rank correlation. Based on the results of this analysis, it was found that IL-6 gene polymorphism influenced the efficacy of AVT, namely, the negativization of HCV-RNA in the blood at the time of treatment completion $(P=0.04)$ and SVR 24 achievement $(P=0.03)$. Along with the influence of this factor on the AVT effectiveness, an increased level of ALT activity before AVT was significant. Non-response at the time of AVT completion as well as non-SVR 12 and non-SVR 24 were associated with the presence of CG/GG genotype of IL- 6 gene polymorphism and the higher level of ALT activity prior to AVT $(P<0.01)$. It should be noted that female patients showed a significant positive effect only in the frequency of RVR achievement $(P=0.02)$, however, the treatment effectiveness did not depend on gender $(P>0.05)$ at the following stages of AVT. In addition, in the use of triple-therapy including direct-acting antiviral drug, there was no effect $(P>0.05)$ on the degree of liver fibrosis severity at all stages of AVT (Table 3).

\section{Discussion}

According to the literature, the search for predictors of response to AVT has continued almost since the first schemes of etiotropic treatment development for $\mathrm{CHC}$ patients. The combination of double AVT with the peg-IFNa + RBV scheme demonstrated the beneficial effects of such factors as genotypes 2 and $3 \mathrm{HCV}$ infection, female sex, white race, overweight and insulin resistance, young age, severe liver fibrosis $[4,6,7]$. With the advent of genotyping of genetic variants of the genes encoding interleukins, IL-28B gene polymorphism was important, but it was relevant only to patients infected with genotype $1 \mathrm{HCV}$ and allowed for differentiate approach to choosing between peg-IFNa + RBV or peg-IFN + BOC/TLV + RBV treatment regimens [8]. However, with the development of SOF-based treatment regimens, this marker has become impracticable $[8,19]$.
Table 2. Comparison of SVR 24 frequency under AVT with peg-IFNa + SOF + RBV regimen in $\mathrm{CHC}$ patients infected with different genotypes of HCV depending on IL-6 gene polymorphism (rs1800795)

\begin{tabular}{|l|l|l|l|}
\multirow{2}{*}{ Genotype of HCV } & \multicolumn{2}{l}{ CHC patients $(\mathrm{n}=83)$} \\
\cline { 2 - 4 } & \multicolumn{2}{|l|}{ Responders with SVR 24 (n=73) } & $\begin{array}{l}\text { Non-responders } \\
\text { with SVR 24 }(\mathrm{n}=10)\end{array}$ \\
\cline { 2 - 4 } & $\begin{array}{l}\text { CC genotype } \\
(\mathrm{n}=14)\end{array}$ & $\begin{array}{l}\text { CG/GG genotype } \\
(\mathrm{n}=59)\end{array}$ & $\begin{array}{l}\text { CG/GG genotype } \\
(\mathrm{n}=10)\end{array}$ \\
\hline Genotype 1 HCV, abs. $(\%)$ & $10(71.4 \%)$ & $35(59.3 \%)$ & $7(70.0 \%)$ \\
\hline Genotype 3 HCV, abs. $(\%)$ & $4(28.6 \%)$ & $24(40.7 \%)$ & $3(30.0 \%)$ \\
\hline
\end{tabular}

Table 3. Correlation matrix of AVT regimen with peg-IFNa + SOF + RBV dependence on various factors in $\mathrm{CHC}$ patients

\begin{tabular}{l|l|l|l|l}
\hline Index & RVR & $\begin{array}{l}\text { Virological } \\
\text { response } \\
\text { at the end of AVT }\end{array}$ & SVR 12 & SVR 24 \\
\hline IL-6 gene polymorphism & $\tau=-0.11$ & $\tau=-0.15^{*}$ & $\tau=-0.17^{*}$ & $\tau=-0.17^{*}$ \\
\hline Genotype HCV & $\tau=-0.013$ & $\tau=-0.001$ & $\tau=-0.06$ & $\tau=-0.06$ \\
\hline Viral load before AVT & $\tau=0.03$ & $\tau=-0.06$ & $\tau=0.005$ & $\tau=0.005$ \\
\hline ALT activity before treatment & $\tau=0.14$ & $\tau=-0.16^{*}$ & $\tau=-0.18^{*}$ & $\tau=-0.18^{*}$ \\
\hline Degree of liver fibrosis & $\tau=0.10$ & $\tau=0.10$ & $\tau=0.001$ & $\tau=0.001$ \\
\hline Age of patients & $\tau=0.09$ & $\tau=-0.05$ & $\tau=-0.12$ & $\tau=-0.12$ \\
\hline Gender of patients & $\tau=0.17^{*}$ & $\tau=0.05$ & $\tau=0.011$ & $\tau=0.011$ \\
\hline
\end{tabular}

*: indicator of Kendall's rank correlation is statistically significant $(P<0.05-0.01)$.

Therefore, the search of new predictors for response to AVT is ongoing with a particular focus on AVT including both peg-IFNa and SOF. At the same time, there are recent studies that demonstrate the clinical and pathogenetic role of $\mathrm{CHC}$ not only in the content of certain cytokines, but also in genetic polymorphisms [8-11].

According to modern literature data, IL-6 participates in immune responses regulating the activity of proinflammatory and anti-inflammatory reactions of the immune system. At the same time, the level of IL-6 production depends on the cytokine gene polymorphism. In particular, the study [20] demonstrated that a G/C single nucleotide polymorphism at the promoter -174 of the IL- 6 gene influenced the IL-6 gene transcription rate and, consequently, controlled the circulating IL-6 levels in the body. G/G and 
G/C genotypes of promoter-174 increased IL-6 level, and $\mathrm{C} / \mathrm{C}$ genotype reduced it. These features of IL-6 production influenced the incidence of chronic $\mathrm{HCV}$ infection as well as the incidence of severe liver fibrosis in $\mathrm{CHC}$ patients [21]. In modern literature, we found a study [22] that demonstrates the negative effect of the $G$ allele presence in the positions rs1800797, rs1800796, rs1800795 on the success of AVT with peg-IFNa + RBV scheme. The data obtained in our study showed that even with the use of SOF-based triple AVT, the G allele presence or rather, the presence of CG/GG genotype of IL-6 gene (rs1800795) polymorphism is a prognostically unfavorable factor for SVR 24 formation in the course of AVT using the scheme peg-IFNa + SOF + RBV in CHC patients.

\section{Conclusions}

1. In CHC patients, the CC genotype of IL- 6 gene (rs1800795) polymorphism is prognostically favorable for SVR 24 formation in AVT administration with the peg-IF$\mathrm{Na}+\mathrm{SOF}+\mathrm{RBV}$ scheme. All patients with the CC genotype responded to the treatment by RVR, the negative result of HCV-RNA was maintained throughout the treatment period with subsequent SVR 24 formation, which was combined with the normalization of serum ALT activity in this period.

2. CHC patients who did not respond by SVR 24 achievement had only CG/GG genotypes of IL-6 polymorphism $(10-100 \%)$. In CHC patients with CG/GG genotype, who responded to AVT by SVR 24 achievement, the negativization of HCV-RNA in the blood was slower, in contrast to patients with CC genotype. Non-response at the time of AVT completion as well as the absence of SVR 12 and SVR 24 formation were associated with the presence of CG/GG genotype of IL-6 gene polymorphism and a higher level of ALT activity prior to the beginning of AVT $(\tau=-0.18, P<0.01)$.

3. The polymorphism of IL-6 gene (rs1800795) should be taken into account when choosing a treatment for $\mathrm{CHC}$ patients. Treatment with peg-IFNa + SOF + RBV is effective for all patients with CC genotype. If CG/GG genotype is detected, different schemes of AVT should be chosen, especially non-interferon-based therapy.

Prospects for further research. Given the obtained data, in our opinion, it is expedient to conduct further studies to broaden knowledge related to $\mathrm{CHC}$ immunopathogenesis, namely the definition of IL-6 quantitative content features associated with the polymorphism of the gene that encodes it, in order to determine the peculiarities of disease course and the effectiveness of various schemes of modern AVT.

Conflicts of interest: authors have no conflict of interest to declare. Конфлікт інтересів: віАсутній.

Information about authors:

Riabokon Yu. Yu., MD, PhD, DSc, Associate Professor of the Department of Children Infectious Diseases, Zaporizhzhia State Medical University, Ukraine.

Kalashnyk K. V., MD, Assistant of the Department of Infectious Diseases, Zaporizhzhia State Medical University, Ukraine. Riabokon 0. V., MD, PhD, DSc, Professor, Head of the Department of Infectious Diseases, Zaporizhzhia State Medical University, Ukraine.
Відомості про авторів:

Рябоконь Ю. Ю., А-р меА. наук, Аоцент каф. Аитячих інфекційних хвороб, Запорізький Аержавний медичний університет, Україна. Калашник К. В., асистент каф. інфекційних хвороб, Запорізький Аержавний меАичний університет, Україна.

Рябоконь О. В., А-р меА. наук, професор, зав. каф. інфекційних хвороб, Запорізький Аержавний медичний університет, Україна.

\section{Сведения об авторах:}

Рябоконь Ю. Ю., А-р меА. наук, Аоцент каф. Аетских инфекционных болезней, Запорожский государственный медицинский университет, Украина.

Калашник К. В., ассистент каф. инфекционных болезней, Запорожский государственный медицинский университет, Украина.

Рябоконь Е. В., А-р меА. наук, профессор,

зав. каф. инфекционных болезней, Запорожский

государственный медицинский университет, Украина.

Навійшла Ао редакції / Received: 02.07.2018

Після Аоопрацювання / Revised: 25.07.2018

Прийнято Ао Аруку / Accepted: 27.08.2018

\section{References}

[1] Golubovska, O. (2016). Primenenie kombinacij lekarstvennykh sredstv dlya lecheniya pacientov s khronicheskim gepatitom C: obzo klinicheskikh issledovanij i osobennosti nacional'nykh standartov terapii [Combination of drugs for treatment of patients with chronic hepatitis $\mathrm{C}$ : a review of clinical trials and features of the national treatment standards]. Klinicheskaya infektologiya i parazitologiya, 3(18) 304-312. [in Russian]

[2] Mohammed, A., Auckle, R., Li, H., Xu, S., Liu, L., Zhao, D., \& Che, W. (2018). Pegylated Interferon-a Plus Ribavirin Therapy Improves Left Ventricular Diastolic Dysfunction in Patients With Chronic Hepatitis C Attaining Sustained Virological Response. The American Journal Of The Medical Sciences, 355(6), 566-572. doi: 10.1016/j. amjms.2018.02.001.

[3] Kozielewicz, D., Grabińska, A., Madej, G., \& Wietlicka-Piszcz, M. (2018) Efficacy and safety of pegylated interferon $\alpha$ and ribavirin in patients monoinfected with HCV genotype 4. Gastroenterology Review, 13(1), 22-29. doi: 10.5114/pg.2018.74558.

[4] (2016) AASLD/IDSA/IAS-USA. HCV Guidance: Recommendations for Testing, Managing and Treating Hepatitis C. Retrieved from http:// www.hcvguidelines.org.

[5] Ministerstvo okhorony zdorovia (2016) Nakaz MOZ Ukrainy «Pro zatverdzhennia ta vprovadzhennia medyko-tekhnolohichnykh dokumentiv zi standartyzatsii medychnoi dopomohy pry virusnomu hepatyti $C$ » vid 18.07.2016 r. №729 [Order of the Ministry of Health of Ukraine «On Approval and Implementation of Medical-Technological Documents for the Standardization of Medical Aid in the Case of Hepatitis C» from July 18, 2016 №729]. [in Ukrainian].

[6] Evon, D., Esserman, D., Bonner, J., Rao, T., Fried, M., \& Golin, C. (2013). Adherence to PEG/ribavirin treatment for chronic hepatitis $\mathrm{C}$ : prevalence, patterns, and predictors of missed doses and nonpersistence. Journal Of Viral Hepatitis, 20(8), 536-549. doi: 10.1111 jvh.12079.

[7] Milara, J., Outeda-Macias, M., Aumente-Rubio, M. D., Más-Serrano, P. Aldaz, A., Calvo, M. V., et al. (2015). PEG-Interferon-a ribavirin-induced HCV viral clearance: a pharmacogenetic multicenter Spanish study. Farm Hosp., 39(1), 29-43. doi: 10.7399/fh.2015.39.1.8547.

[8] Mechie, N., Röver, Ch., Cameron, S., \& Amanzada, A. (2014). Predictability of IL-28B-polymorphism on protease-inhibitor-based triple-therapy in chronic HCV-genotype-1 patients: A meta-analysis. World Journal Of Hepatology, 6(10), 759-765. doi: 10.4254/wjh.v6.i10.759.

[9] Suppiah, V., Moldovan, M., Ahlenstiel, G., Berg, T., Weltman, M. Abate, M., et al. (2009). IL28B is associated with response to chronic hepatitis $C$ interferon- $\alpha$ and ribavirin therapy. Nature Genetics, 41(10), 1100-1104. doi: 10.1038/ng.447.

[10] Guo, P., Li, G., Sun, X., \& Wu, D. (2016). Influence of IL10 Gene polymorphisms on the sustained virologic response of patients with chronic hepatitis C to PEG-interferon/ribavirin therapy. Infection, Genetics And Evolution, 45, 48-55. doi: 10.1016/j.meegid.2016.08.016.

[11] Sadeghi, S., Davari, M., Asli, E., Gharibzadeh, S., Vaziri, F., Jamnani, F. et al. (2017). Effect of IL15 rs10833 and SCARB1 rs10846744 on virologic responses in chronic hepatitis $C$ patients treated with pegylated interferon- $\alpha$ and ribavirin. Gene, 630, 28-34. doi: 10.1016/j. gene.2017.08.005. 
[12] Vince, A., Duvnjak, M. \& Kurelac, I. (2013). Treatment guidelines for patients with genotype 1 chronic hepatitis C infection. Acta Medica Croatica, 67(4), 329-38.

[13] Coppola, N., Pisaturo, M., Sagnelli, C., Sagnelli, E., \& AngelilIo, I. (2014). Peg-Interferon Plus Ribavirin with or without Boceprevir or Telaprevir for HCV Genotype 1: A Meta-Analysis on the Role of Response Predictors. Plos ONE, 9(4), e94542. doi: 10.1371/journal. pone.0094542.

[14] Gower, E., Estes, C., Blach, S., Razavi-Shearer, K., \& Razavi, H. (2014). Global epidemiology and genotype distribution of the hepatitis C virus infection. Journal Of Hepatology, 61(1), S45-S57. doi: 10.1016/j.jhep.2014.07.027.

[15] European Association for the Study of the Liver (2017). EASL Recommendations on Treatment of Hepatitis C 2016. J. Hepatology, 66(1), 153-194. doi: 10.1016/j.jhep.2016.09.001.

[16] Koff, R. (2014). Review article: the efficacy and safety of sofosbuvir, a novel, oral nucleotide NS5B polymerase inhibitor, in the treatment of chronic hepatitis C virus infection. Alimentary Pharmacology \& Therapeutics, 39(5), 478-487. doi: 10.1111/apt.12601.

[17] Donaldson, E. F., Harrington, P. R., O'Rear, J. J., \& Naeger, L. K. (2014). Clinical evidence and bioinformatics characterization of potential hepatitis $C$ virus resistance pathways for sofosbuvir. Hepatology, 61(1), 56-65. doi: 10.1002/hep.27375.

[18] Keating, G. M. (2015). Ledipasvir/Sofosbuvir: A Review of Its Use in Chronic Hepatitis C. Drugs, 75(6), 675-685. doi: 10.1007/s40265015-0381-2.

[19] Petta, S., Cabibbo, G., Enea, M., Macaluso, F., Plaia, A., Bruno, R. et al. (2014). Cost-effectiveness of sofosbuvir-based triple therapy for untreated patients with genotype 1 chronic hepatitis C. Hepatology, 59(5), 1692-1705. doi: 10.1002/hep.27010.

[20] Giannitrapani, L., Soresi, M., Balasus, D., Licata, A., \& Montalto, G. (2013). Genetic association of interleukin-6 polymorphism $(-174 \mathrm{G} / \mathrm{C})$ with chronic liver diseases and hepatocellular carcinoma. World Journal Of Gastroenterology, 19(16), 2449-55. doi: 10.3748/ wjg.v19.i16.2449.

[21] Cussigh, A., Falleti, E., Fabris, C., Bitetto, D., Cmet, S., Fontanini, E., et al. (2011). Interleukin 6 promoter polymorphisms influence the outcome of chronic hepatitis C. Immunogenetics, 63(1), 33-41. doi: 10.1007/ s00251-010-0491-7.

[22] Yee, L. J., Im, K., Borg, B., Yang, H., \& Liang, T. (2009). Interleukin-6 haplotypes and the response to therapy of chronic hepatitis $C$ virus infection. Genes \& Immunity, 10(4), 365-372. doi: 10.1038/gene.2009.26. 